Tohoku J. exp. Med., 1972, 106, 249-251

\title{
In Vitro Inhibition Study of Diphenylhydantoin upon Rat Liver Enzymes Goncerned in Folic Acid Metabolism
}

\author{
Kuniaki Narisawa, Yoshiyuki Honda, Toshio Yoshida \\ and Tsuneo Arakawa \\ Department of Pediatrics, Tohoku University School of \\ Medicine, Sendai
}

Narisawa, K., Honda, Y., Yosmda, T. and Arakawa, Ts. In Vitro Inhibition Study of Diphenylhydantoin upon Rat Liver Enzymes Concerned in Folic Acid Metabolism. Tohoku J. exp. Med., 1972, $106(3), 249-251$ - Results of in vitro study using rat liver homogenates revealed that there was no inhibitory effect of diphenylhydantoin (50 $\gamma$ per $\mathrm{ml}$ of the reaction mixture) upon histidase, urocanase, formiminotransferase, $N^{5,10}$-methylenetetrahydrofolate reductase, formyltetrahydrofolate synthetase, serine-hydroxymethylase and glycine cleavage enzyme. diphenylhydantoin; folic acid

In 1965 Hamfelt and Wilmanns reported that diphenylhydantoin, phenobarbital, or primidone had no inhibitory action on dihydrofolate reductase, methylene tetrahydrofolate dehydrogenase or formyltetrahydrofolate synthetase, which were extracted from an acetone-dried powder of pigeon liver.

The results of present investigation revealed no inhibitory action of diphenylhydantoin on the enzyme systems concerned in folic acid metabolism in rat liver, such as histidase, urocanase, glycine cleavage enzyme, $N^{5,10}$-methylenetetrahydrofolate reductase, serine-hydroxymethylase, formyltetrahydrofolate synthetase, and formiminotransferase.

\section{Materials and Methods}

Histidase activity of the rat liver was estimated by Tabor and Mehler's method (1955): $200 \mathrm{mg}$ of the liver specimens were homogenized with $4 \mathrm{ml}$ of $0.1 \mathrm{M}$ sodium pyrophosphate buffer of $\mathrm{pH} \mathrm{9.2,} \mathrm{and} \mathrm{the} \mathrm{homogenate} \mathrm{was} \mathrm{centrifuged} \mathrm{at} 600 \times \mathrm{g}$ for $10 \mathrm{~min}$, then $0.4 \mathrm{ml}$ of the supernatant was used for the assay.

Urocanase activity of the rat liver was estimated by Tabor and Mehler's method (1955): $200 \mathrm{mg}$ of the liver specimens were homogenized with $5 \mathrm{ml}$ of saline, and the homogenate was centrifuged at $600 \times \mathrm{g}$ for $10 \mathrm{~min}$, then $0.5 \mathrm{ml}$ of the supernatant was used for the assay.

$\mathrm{N}^{5,10}$-methylenetetrahydrofolate reductase activity of the rat liver was estimated by Kutzbach et al.'s method (1967) and the detailed procedures were the same as described in a previous paper of ours (Narisawa et al. 1968) except that $0.41 \mu$ moles of ${ }^{14} \mathrm{C}$-methyllabeled-N $\mathrm{N}^{5}$-methyl-DL-tetrahydrofolic acid (specific activity of $2,997 \mathrm{cpm}$ per m $\mu$ mole) was used.

Received for publication, July 27, 1971. 
TABLE 1. In vitro study of inhibitory effect of diphenylhydantoin upon glycine-cleavage tetrahydrofolate reductase, formiminotransferase,

\begin{tabular}{|c|c|c|c|}
\hline $\begin{array}{l}\text { Enzyme activity } \\
\text { Amount } \\
\text { of diphenyl- } \\
\text { hydantoin } \\
\text { added to the } \\
\text { reaction mixture } \\
\text { (per ml) }\end{array}$ & $\begin{array}{l}\text { Glycine-cleavage } \\
\text { enzyme } \\
\text { (cpm of }{ }^{14} \mathrm{CO}_{2} \text { from } \\
\text { glycine-1 }{ }^{14} \mathrm{C} \text { per } 10 \\
\text { mg protein per hour) }\end{array}$ & $\begin{array}{l}\mathrm{N}^{5,10} \text { methylene- } \\
\text { tetrahydrofolate } \\
\text { reductase } \\
\text { (cpm of }{ }^{14} \mathrm{C}- \\
\text { formaldehyde per } \\
\text { mg protein per hour) }\end{array}$ & $\begin{array}{l}\text { Serine-hydroxy- } \\
\text { methylase } \\
\text { (m } \mu \text { moles of } \mathrm{N}^{5}, 10_{-} \\
\text {methenyltetrahydro- } \\
\text { folate per mg } \\
\text { protein per hour) }\end{array}$ \\
\hline $\begin{array}{c}0 \\
50 \gamma \\
100 \gamma\end{array}$ & $\begin{array}{l}3,053 \\
3,063 \\
3,165\end{array}$ & $\begin{array}{l}20,243 \\
20,643 \\
20,178\end{array}$ & $\begin{array}{l}1,248 \\
1,264 \\
1,440\end{array}$ \\
\hline
\end{tabular}

The activities of formyltetrahydrofolate synthetase and serine hydroxymethylase activity of the rat liver were estimated by Bertino et al.'s method (1962) and detailed procedures were the same as described in a previous paper of ours (Arakawa et al. 1967) except that $1 \mathrm{~g}$ of the liver specimen was homogenized with $7 \mathrm{ml}$ of $0.05 \mathrm{M}$ potassium phosphate buffer of $\mathrm{pH} 7.5$ and the homogenate was centrifuged at $600 \times \mathrm{g}$ for $10 \mathrm{~min}$, then the supernatant was diluted with iced water up to $1: 4,0.2 \mathrm{ml}$ of which being used for assay.

The activity of the glycine cleavage enzyme of the rat liver was estimated in the same way as described in a previous paper of ours (Tada et al. 1989).

The formiminotransferase activity of rat livers was estimated by Tabor and Wyngarden's method (1959).

A stock solution of diphenylhydantoin was prepared by dissolving $50 \mathrm{mg}$ of sodium diphenylhydantoin in $1.0 \mathrm{ml}$ of a solvent containing $40 \%$ propylene glycol and $10.5 \%$ ethanol. The stock solution was diluted with water and this was used for the experiment.

\section{Results and Discussion}

The results were shown in Table 1 , revealing that diphenylhydantoin, at a concentration of $50 \gamma$ per $\mathrm{ml}$ of the reaction mixture, had no inhibitory action upon glycine cleavage enzyme, $\mathrm{N}^{5,10}$-methylenetetrahydrofolate reductase, serinehydroxymethylase, formyltetrahydrofolate synthetase, formiminotransferase, histidase and urocanase of the rat liver.

\section{References}

1) Arakawa, Ts., Narisawa, K., Tanno, K., Ohara, K., Higashi, O., Honda, Y., Tamura, T., Wada, Y., Mizuno, T., Hayashi, T., Hirooka, Y., Ohno, T. \& Ikeda, M. (1967) Megaloblastic anemia and mental retardation associated with hyperfolic-anemia: Probably due to $\mathrm{N}^{5}$-methyltetrahydrofolate transferase deficiency. Tohoku J. exp. Med., 93, $1-22$.

2) Bertino, J.R., Simmons, B. \& Donohue, D.M. (1962) Purification and properties of the formate activating enzyme from erythrocytes. J. biol. Chem., 237, 1314-1318.

3) Hamfelt, A. \& Wilmanns, W. (1965) Inhibition studies on folic acid metabolism with drugs suspected to act on the myeloproliferative system. Clin. chim. Acta, 12, 144152.

4) Kutzbach, C., Galloway, E. \& Stokstad, E.L.R. (1967) Influence of vitamin $B_{12}$ and methionine on levels of folic acid compounds and folate enzymes in rat liver. Proc. Soc. exp. Biol. Med., 124, 801-805. 
enzyme, serine-hydroxymethylase, formyltetrahydrofolate synthetase, $N^{5,10}$-methylenehistidase and urocanase of rat liver

\begin{tabular}{c|c|c|c}
\hline $\begin{array}{c}\text { Formyltetrahydrofolate } \\
\text { synthetase }\end{array}$ & Formiminotransferase & Histidase & Urocanase \\
$\begin{array}{c}\text { (m } \mu \text { moles of } \mathrm{N}^{5,10-} \\
\text { methenyltetrahydro- } \\
\text { folate per mg } \\
\text { protein per hour) }\end{array}$ & $\begin{array}{c}\text { (m } \mu \text { moles of } \mathrm{N}^{5,10}- \\
\text { methenyltetrahydro- } \\
\text { folate per min per } \\
\text { mg wet weight })\end{array}$ & $\begin{array}{c}(\mu \text { moles of urocanate } \\
\text { formed per } \\
\text { weight per hour })\end{array}$ & $\begin{array}{c}(\mu \text { moles of uroca- } \\
\text { nate disappeared } \\
\text { per g wet weight } \\
\text { per hour })\end{array}$ \\
\hline 720 & 0.520 & 39.0 & 9.82 \\
704 & 0.510 & 37.8 & 9.42 \\
704 & & 9.66
\end{tabular}

5) Narisawa, K., Tamura, T., Tanno, K., Ohara, K. \& Arakawa, Ts. (1968) Tetrahydrofolatedependent enzyme activities of the rat liver in riboflavin deficiency. Tohoku $J$. exp. Med., 94, 417-430.

6) Tabor, H. \& Mehler, A.H. (1955) Histidase and urocanase. Methods in Enzymology, $2,228-233$.

7) Tabor, H. \& Wyngarden, L. (1959) The enzymatic formation of formiminotetrahydrofolic acid, 5, 10-methenyltetrahydrofolic acid, and 10-formyltetrahydrofolic acid in the metabolism of formiminoglutamic acid. $J$. biol. Chem., 234, 1830-1846.

8) Tada, K., Narisawa, K., Yoshida, T., Konno, T., Yokoyama, Y., Nakagawa, H., Tanno, K., Mochizuki, K., Arakawa, Ts., Yoshida, T. \& Kikuchi, G. (1969) Hyperglycinemia: A defect in glycine cleavage reaction. Tohoku J. exp. Med., 98, 289-296. 